\title{
THE EFFECTS OF PARTNERSHIPS ON THE EFFICIENCY OF MUSTARD FARMING AT MEGAMENDUNG DISTRICT
}

\author{
Annisa Fitri ${ }^{* 11}$, Harianto**), and Ratna Winandi Asmarantaka**) \\ *) Postgraduate Program of Agricultural Economics Study Program, Bogor Agricultural University \\ Kamper Road, Wing 4 Level 5, IPB Darmaga Campus, Bogor 16680 \\ ${ }^{* *}$ Department of Agribusiness, Faculty of Economics and Management, Bogor Agricultural University \\ Kamper Road, Wing 4 Level 5, IPB Darmaga Campus, Bogor 16680
}

\begin{abstract}
Partnership arrangement leads to differences in the production and management of mustard farming between partner farmers and non-partner farmers. Partnership can affect input and output prices, cultivation techniques, and productivity of mustard. The objectives of this study were to identify factors that affect farmer participation in partnerships, effects of partnership on efficiency, and factors affecting inefficiency in mustard farming. The research used cross-sectional data from a sample of 70 mustard farmers, consisting of 35 farmers with partnership arrangement and 35 farmers with no partnership. The methods used were logistic regression analysis, stochastic frontier production function, and dual cost function. The research results show that factors affecting farmers to get involved in partnership are productivity and income. By participating in partnerships, farmers' farming will be more technically efficient but allocatively and economically inefficient. Factors affecting technical inefficiency include education, number of family members and participation in partnerships. The results of the research also show that partnerships may create opportunities to the farmers to increase their farming productivity. However, they still need facilitation or assistance from the government or local institutions especially in formulating the contract agreement.
\end{abstract}

Keywords: efficiency, logistic regression, mustard greens, partnership, stochastic frontier

Abstrak: Kemitraan mengakibatkan perbedaan dalam proses produksi maupun manajerial usahatani sawi antara petani mitra dan petani nonmitra. Kemitraan dapat mempengaruhi harga input dan output, teknik budidaya, dan produktivitas sawi. Penelitian ini betujuan untuk mengidentifikasi faktor-faktor yang mempengaruhi petani berpartisipasi dalam kemitraan, pengaruh kemitraan terhadap efisiensi usahatani sawi, dan faktor-faktor yang mempengaruhi inefisiensi teknis usahatani sawi. Penelitian ini menggunakan data cross section dari 70 sample petani sawi, yang terdiri dari 35 petani mitra dan 35 petani nonmitra. Metode yang digunakan adalah analisis regresi logistik, fungsi produksi stochastic frontier, dan fungsi biaya dual. Hasil penelitian menunjukkan faktor-faktor yang mempengaruhi petani untuk bermitra adalah pendidikan. Petani mitra efisien secara teknis, tetapi secara alokatif dan ekonomis belum efisien. Faktor yang mempengaruhi penurunan inefisiensi teknis usahatani sawi adalah pendidikan dan dummy penyuluh. Hasil penelitian menunjukkan bahwa kemitraan dapat memberikan peluang bagi petani untuk meningkatkan produktivitas usahataninya, hal ini diliat dari nilai efisiensi teknis petani mitra lebih tinggi dibandingkan petani nonmitra. Namun demikian, petani memerlukan fasilitasi dari pemerintah atau lembaga lokal terutama dalam penyusunan, mediasi, dan pengawasan perjanjian kontrak.

Kata kunci: efisiensi, regresi logistik, sawi hijau, kemitraan, stochastic frontier

\footnotetext{
${ }^{1}$ Corresponding author:

Email: ncepnugraha@gmail.com
} 


\section{INTRODUCTION}

Horticulture is an agricultural sub-sector that is strategic and important, because its role as food pattern of hope. According to the Dirjenhorti (2016), horticultural commodities especially vegetables play an important role for the balance of food consumption; therefore, it must be available at any time in sufficient quantities, good quality, safety, affordable prices and can be accessed by the communities. One vegetable commodity demanded by the communities is mustard. The Indonesian mustard consumption increased positively by $40.27 \%$ from 2014 (1.49 kg/capita/ year) to 2015 (2.09 kg/capita/year) (Pusdatin, 2016). A mustard plant contains minerals, vitamins, proteins and calories. The parts of the mustard that are used for both fresh and processed food are the leaves or flowers (vegetables). Therefore, the mustard plant becomes a potential and prospective vegetable commodity in Indonesia.

Increased consumption of mustard in Indonesia is not followed by increased production of the plants. Based on BPS (2015), the production of mustard in Indonesia fluctuated and tended to decrease from $2014(602,468$ tons) to 2015 (600.188) by $0.38 \%$. Li (2000) states that there are three ways of increasing the production: (1) increasing the use of inputs of production facilities; (2) applying new technologies; and (3) managing production organizations with technology available to increase production. One effort to overcome the problem of the decreasing production of mustard is the organizational management through partnership. According to Igweoscar (2014) and Kalimang et al. (2014), partnership is effective to improve productivity and technical efficiency levels. The partnership in agriculture becomes a business strategy built to create mutually beneficial relationships (Hafsah, 2000), so it can be market driving force (Kaur, 2014) to build strong marketing channels between companies and small farmers (Champika \& Abeywickrama, 2014) and become a model of production and price risk mitigation in horticultural farming (Saptana and Daryanto, 2013).

According to Mariyah (2016), partnership seen from the contract system is divided into two types, namely, the production contract and marketing contract. The farmers are bound by the production contract must prepare land, labor and equipment, while the company provides inputs and technical assistance to obtain an output supply with quality, quantity and price determined previously. The farmers bound by the marketing contract have the freedom to produce, and the contract is only specified on the quantity and quality of the transacted products and the price determined previously. Implementation of partnership contract production system and marketing contract can be seen in Bogor District, especially in Megamendung District. The partnership between PT Sayuran Siap Saji in Megamendung District and the mustard farmers is in the form of market access and technical guidance through extension and transportation of the harvested crops; thus, it becomes a driving force factor to increase the production of mustard.

The partner farmers can supply the production of the mustard produced under the terms specified by the company in an agreement contract including the agreement on price, payment, and quality. The regulation is established when the agreement contract set up influences the production behavior of the farmers in their farming businesses, so there will be differences between the farmers who do not join partnership (non-partner) and those who join the partnership. It is necessary to investigate the factors that influenced farmers in becoming the partners of the company.

The result of the empirical study of Milliondry (2014) shows that in Megamendung District, productivity of the mustard partner farmers was 10.82 tons/ha lower than that of the non-partner farmers i.e. 11.78 tons/ha. The result is contradictory to theories and empirical studies which suggest that partnership is a solution to increase productivity as stated by Hafsah (2000); Champika \& Abeywickrama (2014); and Fanani et al. (2015). The low productivity of partner farmers is thought to be caused by the allocation of input usage which is not optimal and the high prices of the inputs so that the partner farmer farming becomes inefficient. The research on the efficiency of mustard farming is still very limited; therefore, this study analyzed the level of technical efficiency, allocative efficiency, and farmer farming system efficiency of the partner farmers and non-partner farmers.

The efficiency of mustard farming is also strongly influenced by the managerial capability of farmers in managing and allocating production inputs. These managerial capabilities can come from internal factors and external factors. The internal factors consist of age, education, experience, while external factors include participation in partnerships, counseling and credit 
assistance. These factors are suspected to affect the management and efficiency of mustard farming. It is also necessary to know the factors that influence the technical inefficiency of the mustard farming system.

Based on the problems, the objectives of this research were: (1) to identify what factors influence the farmers to become the partners of the company, (2) to analyze technical, allocative and economic efficiency of the partner farmers and non-partner farmers, and (3) to analyze factors which affect the technical inefficiency of the mustard farming system.

The research was conducted at PT Sayuran Siap Saji at Megamendung District from March 2017 to May 2017 with its green mustard commodity. This research analyzed the factors that influenced farmers to become partners. This study measured the technical, allocative, and economic efficiency of mustard farming of the partner farmers and non-partner farmers. This research also analyzed the factors that influenced technical inefficiency of mustard farming. The analytical tools used in this research included logistic regression, stochastic frontier production function, and dual cost function.

\section{METHODS}

This research was conducted in Megamendung District Bogor. Site selection was carried out purposively with the consideration that: 1) it has the highest productivity in Bogor Regency, and 2) it has an easier access to market. The study was conducted from March 2017 to May 2017.

This study used the primary data obtained from the interviews with farmers with a questionnaire guide. The data used were cross section data. Based on the data from the extension workers of the company, the number of the partner farmers of PT Sayuran Siap Saji reached 35 farmers, so that these 35 farmers became the samples of this research. Sampling for non-partner farmers was conducted by snowball as many as 35 farmers with the total of 70 farmers involved in this research.

The factors affecting the partner farmers were analyzed using the logistic regression. The logit model describes the qualitative responses of the dependent variables. The advantages of the logistic regression model is that it does not require the assumption of normality, heterocedastity, and autocorrelation because the dependent variables on logistic regression are dummy variables ( 1 and 0$)$, so the residual does not require the test (Firdaus and Afendi, 2008). The partnership decision model in this research is formulated by the following equation:
$\operatorname{Logit}(\mathrm{Pi})=\ln (\mathrm{pi} / 1-\mathrm{pi})=\beta 0+\beta 1 \mathrm{X} 1+\beta 2 \mathrm{X} 2+\beta 3$ $\mathrm{X} 3+\beta 4 \mathrm{X} 4+\beta 5 \mathrm{X} 5+\beta 6 \mathrm{X} 6$

Where: Pi (Probability that a farmer becomes a partner (1) or a non-partner (0)); X1(Age (year)); $\mathrm{X} 2$ (Experience (year)); X3 (Education (year)); X4 (Number of the family members (person)); X5 (Land width (ha)); X6 (Distance from the land to the company $(\mathrm{km})$ ); The expected parameter signals were $\beta 1, \beta 2, \beta 3, \beta 4, \beta 5 \beta 6, \beta 7>0$.

The results of the interpretation of the partnership decision model can be seen from the value of odds ratio used to facilitate the interpretation of coefficients. The value of the odds ratio interprets an opportunity that could be interpreted as the ratio of the farmers' opportunity to partner with the non-partner farmers of the response variables. The outcome of the participation opportunity for partnership serves as a factor of technical inefficiency. The approach was conducted using the Eviews 9 software.

The empirical model in this research used the production function model of stochastic frontier Cobb Douglass. The advantages of this model are as follows (Soekartawi, 2003): (1) the equation can be changed in a linear form; (2) the coefficient of the cobb douglas production function directly describes the production elasticity of each input; (3) the elasticity of production indicates the level of returns to scale, making it easier to describe the state of the business scale of the production process, whether it is increasing, constant, or decreasing; (4) transformation of the linear form of the doubllass cobb function into a $\log$ e form $(\ln )$ results in very small data variations and can reduce heterocedastity. From the stochastic frontier production function model, two conditions can be seen simultaneously i.e. the factors that affect the efficiency and those that affect the inefficiency of farming techniques. The following equation can be formulated:

$\operatorname{Ln} \mathrm{Y}=\beta 0+\beta 1 \ln \mathrm{X} 1+\beta 2 \ln \mathrm{X} 2+\beta 3 \ln \mathrm{X} 3+\beta 4 \ln \mathrm{X} 4+$ $\beta 5 \ln X 5+\beta 6 \ln \mathrm{X} 6+\beta 7 \mathrm{D} 1+\mathrm{e}(\mathrm{g})$ 
Where: Y (Mustard production of the non-partner farmers (kg)); X1 (Area width (ha)); X2 ( A m o u n t of seeds of mustard (gram)); X3 (Manure (kg)); X4 (Inorganic fertilizer (kg)); X5 (Pesticide (litre)); X6 (Laborer (per day per person)); $\beta 0$ (Intercept or Constanta); $\beta \mathrm{i}$ (Regression coefficient of the production factor/estimation parameter $(\mathrm{i}=1,2, . .6)$ ); D1 (Dummy variable for the partner farmers (partner farmer $=1$ and non-partner farmer $=0))$; $(\mathrm{g})$ (error, where $(\mathrm{g})=\mathrm{Vi}-\mathrm{Ui})$; vi (symmetric, normally distributed random error); ui (a one-side error term (ui :0)); vi-ui (Effect on the model technique inefficiency). The expected parameter values of $\beta 1, \beta 2, \beta 3, \beta 4, \beta 5, \beta 6>0$ are expected to give a positive estimation parameter value.

\section{Technical Efficiency}

Technical efficiency is the ratio of the actual production by the farmers to the maximum technical level of production probability. Technical efficiency is measured using the following formula:

$$
\begin{aligned}
\mathrm{TE} & =y i / y^{*}=y i / \exp (x i \beta)=\exp (x i \beta+v i-u i) / \exp (x i \beta+v i) \\
& =\exp (\text { ui) } \mathrm{i}=1,2,3 \ldots \mathrm{N}
\end{aligned}
$$

Where: yi is the actual production from the observations and $\mathrm{y}^{*}$ is the frontier production estimation obtained from the stochastic frontier. The technical efficiency for a farmer ranges from zero to one or a TEI value of $0 \leq \mathrm{TEi} \leq 1$. The farmers' efficient technical efficiency value is $>0.7$ (Coelli et al. 1998).

\section{Analysis on the Technical Efficiency Factors}

The technical inefficiency factors refer to the technical inefficiency effect model developed by Coelli et al. (1998) as expressed below:

$$
\mathrm{Ui}=\delta 0+\delta 1 \mathrm{Z} 1+\delta 2 \mathrm{Z} 2+\delta 3 \mathrm{Z} 3+\delta 4 \mathrm{Z} 4+\delta 5 \mathrm{Z} 5+\delta 6 \mathrm{D} 1
$$

Where: Ui (technical inefficiency effect); $\delta 0$ (constanta); Z1(farmer age (year)); Z2 (farmer formal education level (year)); Z3 (farming experience (year)); Z4 (Number of family members (person)); Z5 (partner farmer participation opportunity); D1(extension dummy (the company extension $=1$, the government extension $=0$ ))

The expected parameter signs were $\delta 1>0$ and $\delta 2 \delta 3 \delta 4$ $\delta 5 \delta 6 \delta 7<0$. The results obtained are consistent with the estimation of production function parameters and inefficiency function performed simultaneously with frontier program 4.1 (Coelli, 1998).

Analysis on Allocative Efficiency and Economic Efficiency

According to Farel (1957), allocative efficiency is the ability to choose the optimal level of output at a particular input price. Economic efficiency is a combination of technical and allocative efficiency. Allocative and economic efficiency is measured by first deriving the dual cost function from the stochastic frontier production function. The measure of economic efficiency is as follows:

$$
\begin{aligned}
\mathrm{EE} & =\mathrm{C}^{*} / \mathrm{CA}=\mathrm{E}(\mathrm{Ci} \mid \mu 1=0, \mathrm{Y} 1, \mathrm{P} 1) / \mathrm{E}(\mathrm{Ci} \mid \mu 1, \mathrm{Y} 1, \mathrm{P} 1) \\
& =\mathrm{E}[\exp (\mathrm{Ui}) / \mathrm{Ei}]
\end{aligned}
$$

Where: $C^{*}$ (Total minimum observed production cost or production dual frontier cost (Pi, Y)); P1, P2 ... P6 (Rental price of land, seeds, manures, urea fertilizers, pesticides, and labor); X1, X2..X6 (Total input area of land, seed, manure, urea fertilizer, pesticide, and labor); Y (Mustard output/production); CA (Total minimum production cost observed).

Thus, the allocative efficiency (AE) per individual farming is derived from the technical and economic efficiency as follows:

\section{$\mathrm{AE}=\mathrm{EE} / \mathrm{TT}$}

Where: $\mathrm{EE}$ is $0 \leq \mathrm{EE} \leq 1$; $\mathrm{EA}$ is $0 \leq \mathrm{EA} \leq 1$. Calculation of allocative and economic efficiencies were conducted using Ms. Excel 2007.

The hypotheses of this research were: (1) age, education, experience, number of family member, distance of land to the company, and land width assumed to have positive effects on the farmer participation to partner; and (2) efficiency level achieved by partner farmers in Megamendung was higher in efficiency, techniques, allocation, and economy compared to that of the nonpartner farmers. (3) Age, education, farmer experience, partner partnership opportunity, extension dummy were assumed to have effects on reducing technical inefficiency.

The management of mustard farming was faced with the technical and socio-economic constraints. Both cause the farmers to be inefficient in the use of inputs for 
maximum profits and outputs. The mustard farming in Megamendung District is influenced by the availability of inputs such as land, seeds, fertilizers, pesticides, and labor. The socioeconomic factors included age, education, experience, number of family members, partner participation opportunity from logistic regression analysis, and extension dummy. These factors were analyzed by using a stochastic frontier production function to know the technical efficiency and inefficiency. The allocative and economic efficiencies used a dual cost function. Efficiency is achieved when farming benefits and gives maximum outputs for the farmers. Efficiency is achieved by the use of optimal inputs, resulting in minimal production costs. The theoretical framework can be seen in Figure 1.

\section{RESULTS}

\section{The Factors Affecting the Mustard Farmers to Partner}

Table 1 presents the factors that influenced the farmers to partner. The result of R-square estimation was $40 \%$, indicating that the dependent variables were explained by the independent variables by $40 \%$ and by the variable outside the model by $60 \%$. The researches using cross section data typically produced small $\mathrm{R} 2$, but what must be considered here is the significance of the variables used (Kusnadi, 2005). The estimation results show the factors that were significantly influential were the age, education, number of family members, and land width.

Education had a positive and tangible effect on participation in partnerships. The value odds ratio of 1.294 indicates that if the farmer's education is higher, the chance of the farmers to participate in partnership is 1,294 times higher. Based on the characteristics of the respondents, the partner farmers' education is diverse from the level of elementary school to university while the non-partner farmers had education from the elementary school to high school. These findings are similar to Rachmawati (2008) and Alfanurani (2015). The level of education has a positive effect on the farmers' decision to join the partnership. The higher the education level of the farmers, their decision making becomes more rational, so that those who have higher education will tend to establish partnerships with the hope that their business will grow.

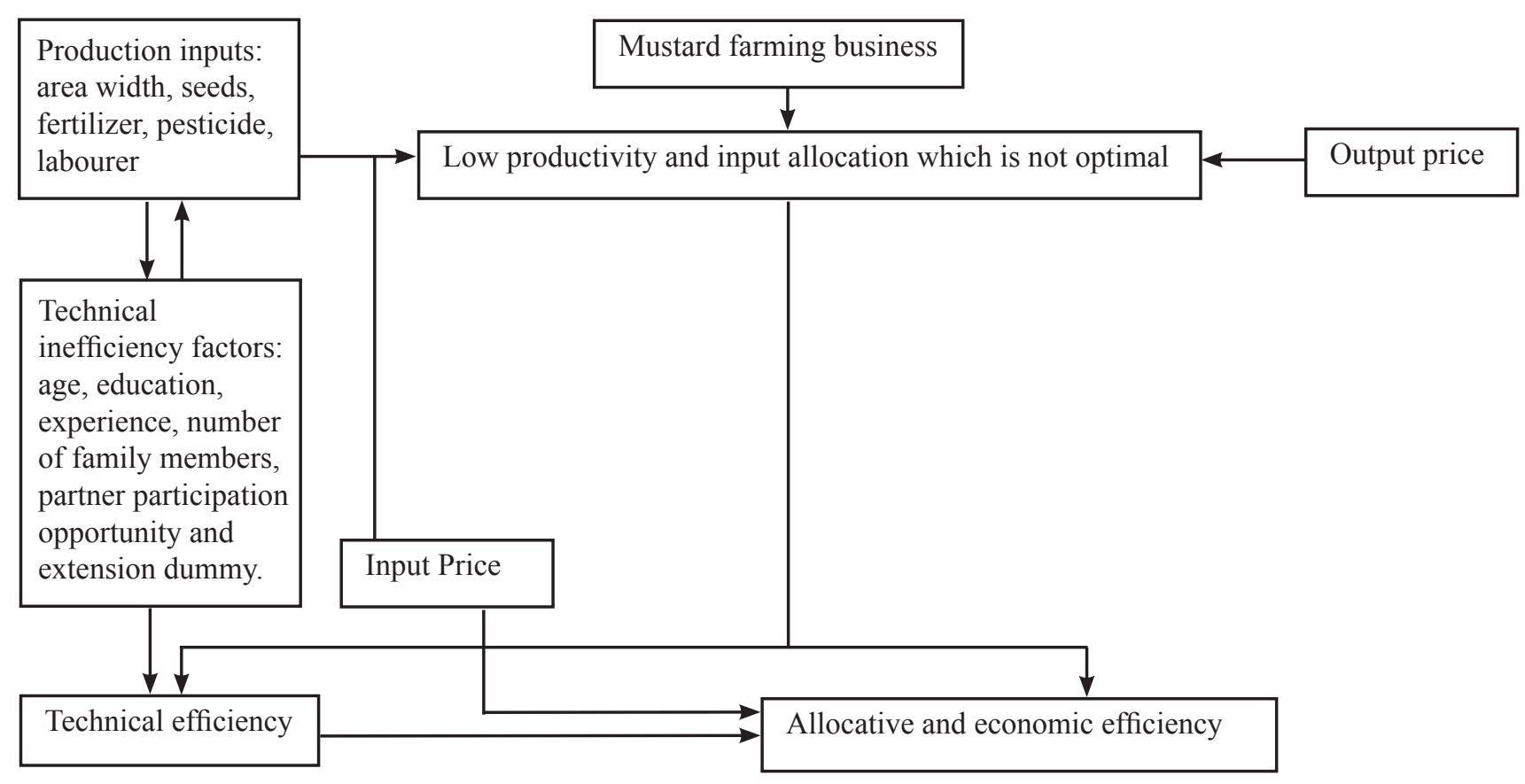

Figure 1. Research framework 
The age variable was significantly influential but with a negative sign. The value odds ratio of 0.928 indicates that if the age of farmers was increasing, the opportunity for them to refuse to partner was 0.928 times higher. Based on the results of the research, both partner farmers and non-partner farmers had a productive average age between 30 year and 50 years. At the productive age, it allows farmers to expand their market. Productive farmers can grow their businesses through partnerships. The results of this study are contradictory to the study by Marliana (2008), stating that the older the farmers, the greater their chances to partner. This is true since older farmers need life insurance. This can be achieved by establishing a partnership for its market guarantee and production factor assistance.

The variable of number of family members was significant but negative. The odds ratio of 0.455 means that if the number of family members increases, the chance of refusing to join a partnership is 0.455 times greater than the willingness to partner. The result of this study is similar to that by Marliana (2008), stating that the larger number of family dependents can encourage farmers to develop their own farms, so they do not need any partnerships. In contrast to the research by Alfanurani (2015) and Rachmawati (2008), the number of families have a positive influence on farmers decision to partner. The higher number of family members of the farmers gives more opportunities for them to partner.

The variable of land area negatively affected the farmer decision to partner. The odds ratio was 0.001 which indicates that farmers who had a large area had the opportunity to refuse to join the partnership of 0.001 times greater compared with the willingness of the partner farmers. Based on the field condition, the partner farmers had narrower land ranging from 0.1 to 0.25 ha while the non-partner farmers had larger land with a range of $0.26-0.5 \mathrm{ha}$. The farmers who had larger land preferred to conduct their own farming compared to those who owned a small area. This research is different from the study conducted by Rachmawati (2008) and Alfanurani (2015) in which the wider the land, the greater the amount of the farmer production; therefore, they need market guarantee which can be obtained by establishing a partnership.

The distance of the farmer land to the company was not significantly influential but negative. This is because PT Sayuran Siap Saji for the mustard commodity only recruits farmers who have land close to the company so that they can be controlled by the company. It provides the transportation facility from the land to the company, with the term that the road is accessible for the vehicle. If the land is far from the company and the road is inaccessible, the farmers tend not to partner. The factors affecting the mustard farmers to partner can be seen in Table 1.

\section{Estimation of Production Function of Mustard}

Estimation of production function was carried out using OLS (ordinary least square), and MLE (Maximum Likelihood Estimation) was carried out using dummy production function. Based on Table 2, the gamma value $(\gamma)$ of 0.959 means that $95.9 \%$ of the yield variations among farmers were due to the differences in technical efficiency while the remaining $4.1 \%$ was caused by stochastic effects outside the model such as climate influence, natural disasters, pest attacks and diseases. The value of generalized-likelihood ratio (LR) in this study was 37.33 still greater than that of the Kodde and Palm table of 11.91 which was significant at $\alpha=5 \%$, indicating that there was an effect of efficiency and technical inefficiency on mustard farming. Partnership dummy had a significant effect on production (frontier). This means that the statistical production of farmers is different from that of non-partners.

Table 1. The factors affecting the mustard farmers to partner

\begin{tabular}{|c|c|c|c|}
\hline Variable & Coeficient & Probability & Odds Ratio \\
\hline Constanta & 8.36 & 0.00 & \\
\hline Age & -0.07 & 0.02 & 0.928 \\
\hline Education & 0.26 & 0.09 & 1.294 \\
\hline Number of family members & -0.79 & 0.00 & 0.455 \\
\hline Distance from the land to the company & -0.22 & 0.11 & 0.803 \\
\hline Land width & -6.70 & 0.00 & 0.001 \\
\hline R-square & 0.40 & & \\
\hline
\end{tabular}


The variables that had significant effects including land area, number of seeds and pesticide. The land input had a coefficient of 0.843 and a significant effect on $\alpha 1 \%$, indicating that if the land area is added by one percent while the other inputs remain the same (cateris paribus), the production of mustard will increase by $0.843 \%$. The results of this study are consistent with the empirical findings made by Gul et al. (2009), Otitoju \& Arene (2010), and Hussain et al. (2012) stating that the wider the land owned by farmers, the more efficient the business. However, the field condition indicates the existence of phenomenon of land transfer function becomes the factor that hamper the development of the business and the decrease of the mustard farming area in Megamendung District.

Increase in the use of seed quantity had a significant effect on the level of $1 \%$ and had a value of elasticity of 0.097 , indicating that if the number of seeds added by $1 \%$ with other inputs remained the same, the production could increase by $0.097 \%$. The rational mustard farmers will increase the quantity of the mustard seeds in order to increase their mustard production. The results of this invention are in accordance with Lawrence et al. (2013) and Jaffar et al. (2016), stating that seeds contribute positively to improving production efficiency.

Thepesticidevariablehadapositiveestimatedcoefficient value and a significant effect on the production of mustard at the level of 5\% and had a value of elasticity equal to 0,034 . This means that each addition of 1 percent of pesticide with other inputs will still increase production by $0.034 \%$. This is in accordance with the research by Sunawirawan (2010) and Pratama (2012) who showed that pesticides affected production.

The urea fertilizer variable has no significant effect, and the geographical condition of Megamendung District is highland, accompanied by an uncertain climate, especially rainy season which leads to faster nutrient leaching in the event of rain. This is because urea fertilizer contains nitrogen element easily soluble in water. The result of stochastic frontier production function estimation at the partner and non-partner farmers in Megamendung District in 2017 can be seen in Table 2.

\section{Technical Efficiency, Allocative Efficiency, and Economic Efficiency}

Mustard farming by the partner and non-partner farmers in Megamendung District is technically efficient. Based on Table 3, the average technical efficiency of the partner farmers was higher by 0.91 with a range of $0.41-0.98$. In the non-partner farmers, the average value of technical efficiency was 0.89 with a range of 0.57 0.98 . The result of the research by Jaffar et al. (2016) obtained a value of 0.86 for their technical efficiency of mustard farming. According to Coelli (1998), farming is said to be efficient if the value reaches $\geq 0.7$.

Table 2. Results of stochastic frontier production function estimation on the partner and non-partner farmers in Megamendung District in 2017

\begin{tabular}{llll}
\hline Variable & Coeficient & Standard-error & t-ratio \\
\hline Constanta & 8.865 & 0.293 & 30.23 \\
Land $(X 1)$ & $0.843 \mathrm{a}$ & 0.040 & 21.01 \\
Seeds (X2) & $0.097 \mathrm{a}$ & 0.040 & 2.43 \\
Urea fertilizer (X3) & 0.017 & 0.018 & 0.91 \\
Pesticides (X4) & $0.034 \mathrm{~b}$ & 0.019 & 1.82 \\
Labour (X5) & 0.012 & 0.050 & 0.24 \\
Dummy (X6) & $-0.127 \mathrm{a}$ & 0.032 & -3.97 \\
Sigma-square $(\sigma 2)$ & 0.125 & 0.058 & 2.15 \\
Gamma $(\gamma)$ & 0.959 & 0.023 & 42.37 \\
L-R test & & & 37.33 \\
\hline
\end{tabular}

Note: $\mathrm{a}$ at $\alpha 0.01$ and $\mathrm{b}$ at $\alpha 0.05$ 
Frontier cost function (isocost frontier) is the result of degradation of stochastic frontier production function with dummy. Table 3 shows the allocative efficiency of partner farming by 0.41 with the range $0.11-0.70$, whereas in the non-partner farmers, the average value of the allocative efficiency was 0.47 with the range of $0.66-0.25$. The low level of allocative efficiency in the research area was influenced by some relatively high production input prices such as land rental rates depending on land conditions, labor prices, urea fertilizer prices, and pesticide prices.

The average value of the economic efficiency of the partner farmers reached 0.37 with the range value of $0.11-0.67$. The non-partner farmers had an average economic efficiency value of 0.42 with the range of $0.17-0.63$. This indicates that mustard farming has not been economically efficient. If they want to achieve maximum economic efficiency, the cost must be (1-0.37/0.67) equal to $44.44 \%$. Moreover, if the nonpartner farmers want to achieve maximum economic efficiency, they must spend the cost $(1-0.42 / 0.63)$ by $34 \%$. Economic efficiency in partner and non-partner farmers can still be improved by improving technical and allocative efficiency. The farming of the partner farmer partners is technically efficient but has not been allocated. This means that they have not been able to use a combination of inputs optimally at minimum cost conditions, so that it is still inefficiently allocative. The technical, allocative, and economic efficiency of the partner and non-partner farmers in Megamendung District in 2017 can be seen in Table 3.

\section{Factors Influencing the Inefficiency of Mustard Farming}

The factors that significantly influenced the technical inefficiency of mustard farming in Megamendung District included education and extension worker dummy. The factors that had an effect on improving the technical inefficiency of mustard farming included the opportunity for partner participation. The results of the parameter estimation model of the technical inefficiency effect of the stochastic frontier production function in Megamendung District in 2017 are presented in Table 4.

Table 3. The technical, allocative, and economic efficiency of the partner and non-partner farmers in Megamendung District in 2017

\begin{tabular}{lcccccc}
\hline \multirow{2}{*}{$\begin{array}{c}\text { Efficiency } \\
\text { Distribution }\end{array}$} & \multicolumn{2}{c}{ Technical Efficiency (\%) } & \multicolumn{2}{c}{ Allocative Efficiency (\%) } & \multicolumn{2}{c}{ Economic Efficiency (\%) } \\
\cline { 2 - 7 } & Partners & Non-partners & Partners & Non-partners & Partners & Non-partners \\
\hline$<0.50$ & 2.86 & 0.00 & 77.14 & 60.00 & 80.00 & 71.43 \\
$0.50 \leq 0.59$ & 0.00 & 2.86 & 8.57 & 28.57 & 11.43 & 22.86 \\
$0.60 \leq 0.69$ & 0.00 & 5.71 & 11.43 & 11.43 & 8.57 & 5.71 \\
$0.70 \leq 0.79$ & 2.86 & 8.57 & 2.86 & 0.00 & 0.00 & 0.00 \\
$0.80 \leq 0.89$ & 17.14 & 8.57 & 0.00 & 0.00 & 0.00 & 0.00 \\
$0.90 \leq 0.99$ & 77.14 & 74.29 & 0.00 & 0.00 & 0.00 & 0.00 \\
Total & 100.00 & 100.00 & 100.00 & 100.00 & 100.00 & 100.00 \\
Average & 0.91 & 0.89 & 0.41 & 0.47 & 0.37 & 0.42 \\
Maximum & 0.98 & 0.98 & 0.70 & 0.66 & 0.67 & 0.63 \\
Minimum & 0.41 & 0.57 & 0.11 & 0.25 & 0.11 & 0.17 \\
\hline
\end{tabular}

Table 4. The result of the estimation of model parameter of the effect of inefficiency of production functional technique of the stochastic frontier on the mustard farming in Megamendung District in 2017

\begin{tabular}{llll}
\hline Variable & Coeficient & Standard error & t-ratio \\
\hline Konstanta & 0.406 & 0.654 & 0.621 \\
Age (Z1) & -0.008 & 0.011 & -0.739 \\
Education (Z2) & $-0.239 \mathrm{~b}$ & 0.128 & -1.867 \\
Participation opportunity to partner (Z3) & $2.076 \mathrm{a}$ & 1.030 & 2.015 \\
Extension worker dummy (Z4) & $-0.871 \mathrm{a}$ & 0.432 & -2.016 \\
Number of family members (Z5) & 0.007 & 0.009 & 0.828 \\
\hline
\end{tabular}


The education variable was significantly influential, meaning that higher education of the farmers can reduce the technical inefficiency of mustard farming by the partner farmers and non-partner farmers. Their formal education can improve their managerial capacity and assist them in making the right decisions in running their farming. Good education helped the farmers use information on inputs well so that they are more efficient. The results of this study are similar to the previous research (Gul et al. 2009; Kusnadi, 2011; Donkoh et al. 2012; Sohail et al. 2012; Khan, 2012) in which education can reduce technical inefficiency.

The extension worker variable was negative and had a significant effect on the reduction of technical inefficiency. This means there is a difference between the company extension workers and the government ones. This is because the company extension workers give the planting program to partner farmers and often make visits to them, so that information and technical guidance become more quickly to be delivered to the farmers. The intensive extension could improve the skills of the farmers in running their mustard farming. Technical guidance from the extension workers made the partner farmers use the production inputs appropriately so that the production became optimal while the government extension workers rarely made the visits to the farmers in the district so that information is not quickly disseminated to the farmers. The research results of Akinbode et al. (2011) showed that frequency of meetings with the extension workers have an effect on the reduction of technical inefficiency, and with their help, the researchers were able to transfer knowledge to farmers so that they could make better decisions in improving their productivity.

The variable of participation to partner had a significant effect, and by participating in the partnership, they could increase technical inefficiency in mustard farming. This is because the contract only focused on contract marketing, and the farmers were free to carry out their production. The contracts were only specified on the quantity and quality of the products being transacted. Meanwhile, production contracts were only for extension and transporting crops, and inputs were provided and bought privately by the farmers. The partner farmers had a relatively narrow land area, resulting in their inability to develop their scale of farming. Narrow land ownership for partner farmers is similar to that of Miyata et al. (2009) who stated that the contract on the apple and green onion farming was a labor intensive crop, indicating that the company preferred smallholder farmers with a large number of family labor. This study differs from that of Pramita (2016) and Hamidi (2009) stating that partnerships have an impact on improving technical efficiency.

\section{Managerial Implications}

The results of this research indicate that by participating in partnerships there are opportunities for the farmers to increase productivity, because their technical efficiency of is higher than that of the non-partner farmers. However, the farmers need to ensure that contractual agreements in partnership have accommodated interests related to the provision of production inputs. Facilitation is required from the government officers or community agencies to assist the farmers in the preparation, mediation, supervision, and enforcement of contracts.

\section{CONCLUSIONS AND RECOMMENDATIONS}

\section{Conclusion}

Based on the objectives and the results of the discussion in the research, it can be concluded that education has a positive effect on the farmer participation opportunity to partner. The efficiency level achieved by the partner farmers is technically efficient with an average value of 0.91 , but it is not allocatively efficient and economically efficient with the average values of 0.41 and 0.37 respectively. The efficiency level achieved by the non-partner farmers is technically efficient with the average value of 0.89 , but it is not alocatively and economically efficient with the average values of 0.47 and 0.42 respectively. The factors leading to a reduction in technical inefficiency in mustard farming include education and dummy of extension workers.

\section{Recommendation}

Improved technical efficiency of partner farmers and non-farmers can be obtained through farm management in technical skills and managerial capability of the farmers. Skill enhancement can be done with the use of fertilizers and pesticides as recommended by the agriculture and the use of certified seeds. Improvement in the farmer managerial capability can be focused on increasing the role of extension workers and the existence of field schools. Allocative efficiency can be 
improved by extension activities by not only focusing on cultivation aspect but also non-technical extension aspect such as information of input and output prices, so as to increase allocative efficiency and economic efficiency. The economic efficiency of the mustard farming by the partner farmers and non-partner farmers can be increased by reducing excessive and expensive inputs, thus reducing farming costs. The improvement of the technical efficiency of both partner and nonpartner farmers can be obtained by farming business management for their technical skills and managerial capacity.

\section{REFERENCES}

Alfanurani. 2015. Pengaruh kemitraan terhadap pendapatan petani ubi jalar di Kabupaten Kuningan [skripsi]. Bogor: Institut Pertanian Bogor.

Akinbode SO, Dipeolu AO, Ayinde I. 2011. An Examination of technical, allocative and economic efficiencies in ofada rice farming in Ogun State Nigeria. African Journal Agricultural Research 6(28):6027-6035. https:// doi.org/10.5897/AJAR11.231.

[BPS] Badan Pusat Statistik. 2015. Statistik Indonesia. Jakarta: Badan Pusat Statistik.

Champika PAJ, Abeywickrama LM. 2014. An Evaluation of Maize Contract Farming System in Sri Lanka: Adoption, Problems and Future Prospects. Tropical Agricultural Research 26(1): 62-73. https://doi.org/10.4038/tar.v26i1.8072.

Coelli T, Rao DSP, Battese GE. 1998. An Introduction to Efficiency and Productivity Analysis. Second Edition. New York: Springer. https://doi. org/10.1007/978-1-4615-5493-6.

Saptana, Daryanto A. 2013.Dinamika Kemitraan Usaha Agribisnis Berdayasaing dan Berkelanjutan. Bogor: Pusat Sosial Ekonomi Pertanian, Badan Penelitian dan Pengembangan Pertanian dan Kementrian Pertanian.

[Dirjenhorti] Direktorat Jenderal Tanaman Hortikultura. 2016. Data produksi hortikultura Indonesia Tahun 2011-2015. Jakarta: Direktorat Jenderal Tanaman Hortikultura.

Donkoh SA, Tachega M, Amowine N. 2012. Estimating technical efficiency of tomato production in Northern Ghana. American Journal of Experimental Agriculture 3(1):56-75. https:// doi.org/10.9734/AJEA/2013/1447.
Farrell MJ. 1957. Measurement of Productive Efficiency. Journal of the Royal Statistical Society120(3):253-290.https://doi. org/10.2307/2343100.

Fanani A, Anggraeni L, Syaukat Y 2015. Pengaruh kemitraan terhadap risiko usahatani tembakau di Kabupaten Bojonegoro Provinsi Jawa Timur. Jurnal Manajemen dan Agribisnis 12(3):194203. https://doi.org/10.17358/JMA.12.3.194.

Firdaus M dan Afendi F M. 2008. Aplikasi Metode Kuantitatif Terpilih untuk Manajemen dan Bisnis. Bogor: IPB Press.

Gul M, Koc B, Dagistan E, Akpinar M. Goksel, PO. 2009. Determination of technical efficiency in cotton growing farms In Turkey: a case study of Cukurova Region. African Journal of Agricultural Research 4(10):944-949.

Hafsah JM. 2000. Kemitraan Usaha, Konsep dan Strategi. Jakarta: PT Penebar Swadaya.

Hamidi H. 2009. Dampak kemitraan terhadap efisiensi usahatani tembakau virginia di Pulau Lombok Nusa Tenggara Barat. Jurnal Agroteksos 19(1-2).

Hussain A, Saboor A, Khan MA, Mohsin AQ, Hassan FU, Anwar MZ. 2012. Technical efficiency of wheat production in Punjab (Pakistan): a cropping zone wise analysis. Pakistan Journal of Life and Social Science 10(2):130-138.

Igweoscar O. 2014. Effect of contract farming on productity and welfare of cassava-based farmers in South Eastern Nigeria. European Journal of Business and Management 6(7):334-339.

Jaffar AH, Maqsood H, Sarwat Z, Muhammad A, Habib A, Muhammad AI. 2016. Estimating the technical efficiency in rapeseed and mustard production: a case study of District Okara. Germany Jounal of agricultural economics 54(4):801-811.

Kalimang`ANN, Kihombo A, Kalimang asi N. 2014. Contribution of contract cocoa production on improving livelihood of smallholder farmers. International Journal of Scientific and Research Publications 4(10):1-10.

Kaur P. 2014. Contract farming of potatoes: a case study of PEPSICO plant. International Journal of Scientific and Research Publications 4(6):1-4.

Khan H. 2012. Measurement of technical, allocative and economic efficiency of tomato farms in Northern Pakistan. Journal of Agricultural Science and Technology 2:1080-1090.

Kusnadi. 2005. Perilaku ekonomi rumah tangga 
petani dalam pasar persaingan tidak sempurna di beberapa provinsi di Indonesia [disertasi]. Bogor: Institut Pertanian Bogor.

Kusnadi N, Tinaprilla N, Susilowati SH, Purwoto A. 2011. Analisis efisiensi usahatani padi di beberapa sentra produksi padi Indonesia. Jurnal Agro Ekonomi 29(1): 25-48. https://doi. org/10.21082/jae.v29n1.2011.25-48.

Lawrence DM, Maganga AM, Nelson M. 2013. Farm household production efficiency in Southern Malawi: an efficiency decomposition approach. Journal of Economics and Sustainable Development 4(3):236-246.

Li LP. 2000. Yield gaps, economic inefficiency and potential for productivitygrowth of rice farms in China [dissertation]. University of the Philippines.

Mariyah. 2016.The role of contract farming system to increase farming efficincy, productivity, and income.UNES Journal of scientech research 1 (1): $15-27$.

Marliana. 2008. Analisis manfaat dan faktor-faktor yang Mempengaruhi keputusan petani terhadap pelaksanaan kemitraan lectuce di PT Saung Mirwan [skripsi]. Bogor: Institut Pertanian Bogor.

Milliondry, DH. 2014. Perbandingan usahatani caisin petani mitra dan non mitra di kecamatan megamendung [skripsi]. Bogor: Institut Pertanian Bogor.

Miyata S, Minot N, Hu D. 2009. Impact of contract farming in income: linking small farmers, packers, and supermarkets in China. World Development Journal 37(11):1781-1790. https:// doi.org/10.1016/j.worlddev.2008.08.025.

Otitoju MA, Arene CJ. 2010. Constraints and determinants of technical efficiency in medium scale soybean production in Benue State, Nigeria. African Journal of Agricultural Research 5(17):2276-2280.

Rachmawati E. 2008. Kemitraan antara Perum Perhutani dengan petani vanili dalam upaya meningkatkan pendapatan petani: studi kasus pengelolaan sumberdaya hutan bersama masyarakat di Desa Padasari, Kecamatan Cimalaka, Kabupaten Sumedang [tesis]. Bogor: Institut Pertanian Bogor.

Pratama, A. 2012. Perbandingan analisis efisiensi teknis dan pendapatan usahatani caisim: pendekatan stochastic production frontier (kasus di Desa Ciaruteun Ilir, Kecam.atan Cibungbulang, Kabupaten Bogor) [skripsi]. Bogor: Institut Pertanian Bogor.

[Pusdatin] Pusat Data dan Informasi Pertanian. 2016. PDB Sektor Pertanian Atas Harga Berlaku. Jakarta: Pusat Data dan Sistem Informasi Pertanian.

Pramita DA. 2016. Model kemitraan dan dampaknya terhadap efisiensi teknis usaha ternak ayam broiler di Kabupaten Limapuluh Kota Sumatera Barat [tesis]. Bogor: Institut Pertanian Bogor.

Soekartawi, 2003. Prinsip Dasar Ekonomi Pertanian, Teori dan Aplikasi. Depok: Rajawali Press.

Sohail N, Latif K, Abbas N, Shahid M. 2012. Estimation of technical efficiency and investigation of efficiency variables in wheat production: a case of Distric Sargodha (Pakistan). Interdisiplinary Journal of Contemporary Research in Business 3(10):897-904.

Sunawirawan.2010. Analisis efisiensi produksi dan pendapatan usahatani sawi di Kota Bandar Lampung [skripsi]. Lampung: Fakultas Pertanian, Universitas Lampung. 